\title{
APPLYING DEBATE TECHNIQUE WITH REBUTTAL TYPE IN SPEAKING CLASS: PRACTICES AND IMPACTS
}

\author{
Intan Vandani Wulan \\ SMPN 1 Sumberpucung, Malang \\ intanvandani.wulan@gmail.com \\ Arie Dewantara \\ Corresponding author \\ SMA Annur Bululawang, Malang \\ arie.dewantara@yahoo.com
}

\begin{abstract}
This study aimed at investigating the roles of debate technique with rebuttal type in a speaking class setting. It was motivated by the fact that EFL students tend to be passive in speaking activities in the classrooms. This present study applied quasi-experimental design by involving two groups of students: the experimental group and control group in which each group consisted of 35 students of a vocational high school in Malang, Indonesia. The findings suggest that the use of debate technique with rebuttal type empowers the learning activities to be more effective and interesting. It provides the issues in the pubic area and increases the critical thinking of the students. The implications and suggestions were also discussed.
\end{abstract}

Keywords: debate technique, rebuttal type, speaking skills, critical thinking

\section{INTRODUCTION}

Speaking is fundamental to human communication which is considered the major competence to be mastered. Accordingly, the English language is a compulsory subject for secondary level students in Indonesia since the main purpose of English language teaching in the country is intended to enable students to use English as a means of communication (Sulistyo, 2012). In fact, however, English Language Teaching (ELT) at the secondary level in Indonesia has not focused on speaking skills. Instead, many English teachers still spend the majority of class time reading and writing practice almost ignoring speaking and listening skills. If the goal of the language course is truly to enable students to communicate in English, then speaking skills should be taught and practiced in the language classroom.

According to Brown (2007), oral communication can be maintained by having three components: fluency, accuracy, and pronunciation. In addition, speaking skills deal with the production and perception of segmental sounds of stressed and unstressed syllables and of the speech melody or intonation (Carter \& Nunan, 2004:56). In conclusion, the components are important in the development of students' speaking skills.

Considering the facts above, there would be a need to implement an appropriate strategy to improve EFL students' speaking skills. Actually, there are many techniques for teaching oral communication, such as acting from script, communication games, discussion, prepared talks, questionnaires, simulation and role-play, and debate technique. One of the strategies that a teacher could use is debate technique. 
There are several previous studies related to the use of debate technique in English teaching and learning activity. All of the studies have been done by different researchers resulting on different findings. Ramlan et al. (2016) investigating the impact of debates found that the most significant outcome of the study is the increase in the level of confidence experienced by participants as a direct result of engaging in debating activities. Most of the subjects acknowledged that participating in a debate helped them to speak in public more confidently. Moreover, it can be concluded that debate technique has a very positive effect on the students' speaking ability, especially in the public speaking confidence in which the passive student turns into an active one.

Another study conducted by Sabbah (2015) revealed that using debates as a strategy to improve students' speaking skills had a significant impact on improving students' speaking proficiency. Quantitative and qualitative data mutually supported the positive conclusions of the study and pointed out that a relatively substantial amount of improvement has occurred along different areas of the three levels of speaking skills of pronunciation, grammar, and vocabulary. Then, Hall (2011) claimed that debate can make students have critical thinking and enhancing professional communication skill for health care environment. It can increase students' confidence, foster respect among students, facilitate students' ability to maintain composure, and enhance the students' ability to articulate their own thoughts based on evidence. Somehow, the students who have participated have admitted that preparing for a debate was stressful and time consuming.

A study conducted by Puspitasari et al. (2016), in contrast, found that both of the students in modified debate and non-modified debate seemed to be afraid of speaking. They could not speak since they were afraid to make mistakes. Secondly, the students have obstacles to determine the topic they want to discuss. Also, the students have not been ready to perform the true debate.

Considering some problems still remain in debate technique in teaching learning process, the researchers focused on investigating the effect of debate technique further. Hopefully, it would reveal whether debate technique effective or not effective to be taught in the secondary levels.

\section{METHOD}

This study investigated the effects of debate technique with rebuttal type on students' speaking skill. The research design applied was quasi experimental by involving two different groups: experimental and control groups, and each group consisted of 35 students. The variables used were debate technique as supplementary materials as the independent variable and the students' speaking ability as the dependent variable. This study was conducted at SMKN 1 Kepanjen located on Jl. Ngadiluwih Kedung Penjaringan, Kedungpedaringan, Kepanjen, Malang, East Java.

There were some steps in the research. First, the researchers conducted the study by considering organizing the teaching procedure in experimental and control group. The experimental group was given a treatment using Debate Technique and the control group was 
treated using a conventional method. The second step was organizing the research instrument. The research instrument of the study was an oral test where students' debate was administered to measure the students' speaking performance in terms of arguments, grammar, vocabulary, and pronunciation. The third step was administering a pre-test at the beginning of research to both experimental and control group in order to find the students' prior knowledge in speaking. The last step was administering the result of the post-test to reveal the results of the treatment in the end of the research. The tests were scored by using the rating scores of the oral test adapted from Brown (2004) and McKay (2006). This research applied inter-rater reliability on post-test where two raters were involved in giving scores in participants' post-test in order to avoid bias and subjectivity from one person. The researcher took the scores from both raters and calculated the data by using agreement coefficient correlations product moment.

\section{FINDINGS AND DISCUSSIONS}

The data were mainly obtained from the speaking tests: pretest and posttest. The pretest was conducted to examine whether the two groups, experimental (EG) and control (CG) groups, were homogenous or not. In contrast, the posttest was administered to find out if there was a significant difference between the two groups.

The results of statistical computation using independent sample t-test showed that the two groups were homogenous before the treatment given. Meanwhile, the results of the treatment as reflected in the posttest can be seen in Table 1.

Table 1. The Results of Independent Sample T-test for EG and CG

\begin{tabular}{|c|c|c|c|c|c|c|c|c|c|}
\hline & & \multicolumn{3}{|c|}{$\begin{array}{l}\text { Levene's Test for } \\
\text { Equality of } \\
\text { Variances }\end{array}$} & \multicolumn{4}{|c|}{ t-test for Equality of Means } & \\
\hline & & $\mathrm{F}$ & Sig. & df & $\begin{array}{l}\text { Sig. } \\
\text { tailed) }\end{array}$ & $\begin{array}{l}\text {-Mean } \\
\text { Difference }\end{array}$ & \multicolumn{2}{|c|}{$\begin{array}{ll} & 95 \% \text { Confid } \\
\text { Std. } & \text { ErrorInterval of t } \\
\text { Differenc } & \text { Difference } \\
\text { e } & \text { Lower }\end{array}$} & $\begin{array}{l}\text { lence } \\
\text { he } \\
\text { Upper }\end{array}$ \\
\hline score & $\begin{array}{l}\text { Equal variance } \\
\text { assumed }\end{array}$ & s.917 & .342 & -4.99968 & .000 & -9.88571 & 1.97762 & -13.83199 & -5.93944 \\
\hline & $\begin{array}{l}\text { Equal variance } \\
\text { not assumed }\end{array}$ & & & -4.99967 .010 & .000 & -9.88571 & 1.97762 & -13.83305 & -5.93838 \\
\hline
\end{tabular}

Statistically, the significance value obtained was .000 which was lower than .005 . It implied that the hypothesis was accepted. From this result of the Independent Sample t-test, the researcher concluded that debate technique by using rebuttal type 'was an effective technique in teaching speaking. Debate technique gave a significant contribution on students' speaking skill. It helped the students to speak excitedly and also increased their confidence in speaking activity. From the findings of the study, it can be concluded that teaching - learning English especially speaking by using debate technique as media is effective to improve students' speaking skill. Debate technique has many advantages: debate allows the students to share and cooperate well with one another, it educates the students about responsibility, encourages creativity, deepens friendships and builds rapport with the teacher and students are motivated and enjoy the activity. Finally, it can improve the students' speaking ability. Debate 
is a form of produced conversation. Within the smaller context of debate students can become livelier and gain more confidence.

In addition, the researcher found that other factors influencing English speaking skill of the students were internal and external factors. Internal factors that influenced students were motivations. Alizadeh (2016) believes that has a very important impact in learning English. In addition, the students need motivation to have confidence in public speaking as stated by Sulistyo et al., (2019) that students need motivation and self-efficacy in the classroom, and teachers need to encourage the students to have more self-efficacy in the language learning so that the outcomes of the language learning will be achieved (Sulistyo, 2018:52). Whereas the external factors influenced the students' interaction. They did not like English lesson and in their daily routines they never use English. Furthermore, English teachers usually teach by using Indonesian language, so the students have limited vocabulary and difficulties to make good sentences.

From the data that have been obtained, it shows that many factors affecting the weakness factors students' speaking ability:

1. Students do not like English lessons.

2. Students have low confidence and motivating using English in public speaking.

3. Students are still afraid when they have wrong English and did want to learning from their mistakes.

Teaching and learning process is not useful if there is no interest and motivation. According to Heriyawati, Sulistyo, and Sholeh (2014), students in general will learn effectively if they are motivated due to challenging and contextual activities. It can be said that the treatment as media to improving students' speaking ability is not useful without increasing the students' interest, motivations, and knowing the students' need. So, the researchers concluded that the treatment and the internal factors of the students should be equal in the implementation of teaching and learning process. The result of this research showed that using debate technique with rebuttal type affected the achievement in speaking ability of the students.

The findings of this study were supported by the studies of different researchers. The study has similarities with the previous study which used debate technique as media to teaching speaking. Yet, the differences between this study with others study is other researchers used the modified-debate technique to teaching speaking in class (Puspitasari, 2016). Ramlan et al. (2016) with the title "The Impact of Debates as a Teaching Strategy in the Classroom to Medical Students" found that the students' speaking skill of the medical students at UniKL Royal College of Medicine Perak Malaysia increased. They suggested that the most significant outcome of the study was the increase in the level of confidence experienced by participants as a direct result of engaging in debating activities. It increases critical thinking skills, and the least impact of the debate among respondents is gaining knowledge. Most of the subjects acknowledged that participating in a debate helped them to speak in public more confidently. 
Hall (2011) claimed that debate can make students have critical thinking and enhancing professional communication skill for health care environment.

However, this study has some weakness in applying the use of debate technique in teaching speaking English. When applied the media, some of the students did not give attention and concentrate. It was because some of the students didn't like English learning. The problem of this study is the students who have participated have admitted that although preparing for a debate was stressful and time consuming. Accordingly, there are some groups of students still not ready when they have a performance and have little material to debate. The students just have little braveness in presenting speaking after it held they has significance result in increasing to speak in English.

\section{CONCLUSION}

Though this activity does help students to gain new knowledge on the topic in question, generally, the participants consider the increase in the level of confidence and critical thinking skills as being the more significant gains achieved through their involvement in the debate. The use of debate technique with rebuttal type makes the learning activity more effective and interesting. It is because debate technique with rebuttal type provides the interesting topic about the issues in the public area, increase the critical thinking of the students, give students' confident, and take the accurate of the data before debate. Rebut the opposite group can make the students more confident and dare to express their opinions in accordance with the data/facts that exist.

The fact remains that the debate can actually be used as a teaching tool/technique in the classroom when students have acquired a reasonably good level of proficiency and facility in the language. It is obviously a technique that can motivate students to challenge one another and encourage them to explore and exploit their facilities in the language for the purpose of exploring and expanding points of arguments with the express objective of winning over the audience and also to convince the opposing side to accepted their stand on the motion being discussed and debated.

\section{REFERENCES}

Alizadeh, M. (2016). The Impact of motivation on English language learning. International Journal of Research in English Education, 1(1), 11-15.

Brown, H. D. (2007). Principles of language learning and teaching. San Fransisco: Longman.

Carter, R., \& Nunan, D. (2004). Teaching English to speakers of other languages. Cambridge: Cambridge University Press.

Hall, D. (2011). Debate: Innovative Teaching to Enhance Critical Thinking and Communication Skills in Healthcare Professionals. 9, 16-19.

Heriyawati, D. F., Sulistyo, T., \& Sholeh, A. (2014). THE IMPLEMENTATION OF CONTENT-BASED APPROACH IN IMPROVING ACADEMIC WRITING SKILLS OF 
Volume 6 Nomor 1 Tahun 2019 eISSN : $25494155-$ pISSN : 23557083

EFL STUDENTS. 9(2)

Puspitasari, P. (2016). Modifying debate as a technique to improve the students'speaking skill at SMAN 2 Metro.

Ramlan, F. A., Kassim, N. M., Pakirisamy, S., \& Selvakumar, V. (2016). The impact of debates as a teaching strategy in the classroom to medical students. E-Academia Journal UiTMT, 5(2), 194-203.

Sabbah, S. R. M. (2015). The Effectiveness of Using Debates in Developing Speaking Skills among English Majors at University of Palestine. Al - Azhar University.

Sulistyo, T. (2012). Scaffolding students' interaction with texts using QAR startegy. Journal on English as a Foreign LanguageEnglish, 2(1), 17-24.

Sulistyo, T. (2018). The Use of Blog-Assisted Language Learning to Improve EFL Learners' Writing Performance. Universitas Negeri Malang.

Sulistyo, T., Mukminatien, N., Cahyono, B. Y., \& Saukah, A. (2019). Enhancing Learners ' Writing Performance through Blog-Assisted Language Learning. International Journal of Emerging Technologies in Learning (iJET), 14(9), 61-73. 